\title{
The choice of bromeliads as a microhabitat by Scinax argyreornatus (Anura, Hylidae)
}

\author{
Pederassi, J. ${ }^{a *}$, Lima $_{\text {MSCS. }}{ }^{*}$, Peixoto, OL. ${ }^{c}$ and Souza, CAS. ${ }^{d}$ \\ aBioma NGO, Rua Queluz, 125, São Cristóvão, CEP 27264-820, Volta Redonda, RJ, Brazil \\ ${ }^{b}$ Federal University of Piaui - UFPI, Amilcar Ferreira Sobral Campus, \\ BR 343, Km 3.5, Meladão, CEP 64800-000, Floriano, PI, Brazil \\ ${ }^{\mathrm{c}}$ Biology Institute - IB, Federal Rural University of Rio de Janeiro - UFRRJ, \\ BR 465 Highway, Km 7, CEP 23890-000, Seropédica, RJ, Brazil \\ ${ }^{d}$ Program on Biological Sciences Behaviour and Animal Biology, Federal University of Juiz de Fora - UFJF, \\ Martelos University Campus, CEP 36036-330, Juiz de Fora, MG, Brazil \\ *e-mail: jonaspederassi@yahoo.com.br; slmauro@ufpi.edu.br \\ Received February 04, 2011- Accepted June 07, 2011 - Distributed May 31, 2012
}

(With 1 figure)

\begin{abstract}
The association of anurans to bromeliads presents different degrees of interaction such as: eventual, obligatory and bromeligen. The frog species Scinax argyreornatus shows a regular association with these plants. The goal of this study is to characterise the degree of association between the frog S. argyreornatus to different species of bromeliads. We identified which species of bromeliad is regularly associated with $S$. argyreornatus and recognised which factors interfere with this association preference. We analysed the Concentration of Relative Dominance of frogs per bromeliad species. As possible criteria for frog association preference to different bromeliads species we established the analysis of leaves number, length and width, number of leaf axils, stored water in the axils, $\mathrm{pH}$ and relative humidity, among other organographic components. Our observations were analyzed by ANOVA followed by the Tukey test. We also evaluated the preference for association by the constancy of Bodenheimer. The correlation matrix indicated that the relative humidity is the factor responsible for the frog-bromeliads association, except for Aechmea sp.. However Aechmea sp. was the species with greater constancy of occupation followed by Quesnelia arvensis and Neoregelia johannis. According to our statistical results, Aechmea sp. and $Q$. arvensis are not different regarding organographic parameters, but differ from $N$. johannis. Our observations suggest that the bromeliads organographic structure and the relative humidity are key conditions which influence the preferences of S. argyreornatus to bromeliad species, while the other features showed no correlation.
\end{abstract}

Keywords: amphibians, Atlantic Rain Forest, bromeliad, ecologic interaction, Quesnelia arvensis, Aechmea sp.

\section{A escolha de bromélias, como micro-habitat, por Scinax argyreornatus (Anura, Hylidae)}

\section{Resumo}

A associação dos anuros às bromeliáceas pode apresentar diferentes graus de interação, como: bromelículas eventuais, bromelículas obrigatórios e bromelígenas. Scinax argyreornatus apresenta uma associação frequente a essas plantas. Propõe-se, neste estudo, qualificar esse grau de associação, buscando identificar qual espécie de bromélia é mais ocupada, reconhecendo os fatores que interferem nessa escolha de ocupação. Analisou-se a Concentração de Dominância Relativa dos anuros por espécie de bromélia, sendo considerados como prováveis critérios de escolha: número, largura e comprimento das folhas, número de axilas foliares, volume de água acumulado, $\mathrm{pH}$ e umidade relativa, entre outros componentes organográficos, que foram submetidos à ANOVA e, sempre que observadas diferenças significativas, ao teste de Tukey. Avaliou-se também a escolha de ocupação pela constância de Bodenheimer. A matriz de correlação apontou a UR\% como o fator responsável pela ocorrência do animal nas bromélias, exceto para Aechmea sp.; entretanto, esta foi a planta com maior Constância de ocupação, seguida por Quesnelia arvensis e Neoregelia johannis. Segundo a ANOVA, Aechmea sp. e $Q$. arvensis não apresentam diferenças entre si do ponto de vista organográfico, mas diferem de $N$. johannis. Foi possível inferir que a estrutura organográfica da planta e a UR\% são as condições que interferem na escolha de ocupação das bromélias por $S$. argyreornatus, enquanto as outras características não demonstraram nenhuma correlação.

Palavras-chave: anfíbios, Floresta Atlântica, bromélia, interação ecológica, Quesnelia arvensis, Aechmea sp. 


\section{Introduction}

Some anurans are specialised at reproducing in bromeliads and are totally dependent on this environment to complete their life cycle (Lehtinen, 2002). Peixoto (1977, 1995) classifies the amphibious anuran species that use bromeliads as an egg-laying site such as bromeligens, and cites, as examples, Gastrotheca fissipes (Boulenger, 1888), Ischnocnema nasuta (A. Lutz, 1925), I. venancioi (B. Lutz, 1959), Flectonotus fissilis (Miranda-Ribeiro, 1920), F. goeldii (Boulenger, 1895), Dendrophryniscus brevipollicatus Jiménez de la Espada, 1871, Crossodactylodes pintoi Cochran, 1938, Scinax perpusillus (A. Lutz and B. Lutz 1939) and Phyllodytes luteolus Wied-Neuwied, 1824. By contrast, those species that can be found in these plants during the whole year, but do not use them to reproduce, are classified as obligatory bromeliad-dwellers. As examples the author mentions Aparasphenodon brunoi Miranda Ribeiro, 1920, Aplastodiscus albofrenatus (A. Lutz, 1924), Scinax cuspidatus (A. Lutz, 1925) and Xenohyla truncata (Izecksohn, 1959). Finally, for this author, anurans that use bromeliads just in drought periods to protect from desiccation are classified as eventual bromeliad-dwellers. Species listed includes Rhinella pygmaea (Myers and Carvalho, 1952), Scinax alter (B. Lutz, 1973), S. similis (Cochran, 1952), S. duartei (B. Lutz, 1951), S. trapicheroi (B. Lutz, 1954), Trachycephalus mesophaeus (Hensel, 1867), T. nigromaculatus Tschudi, 1838, Sphaenorhynchus orophilus (A. Lutz and B. Lutz 1938) and Brachycephalus ephippium (Spix, 1824).

Anurans that are bromeligen or obligatory bromeliad dwellers have access to a diverse array of bromeliad species in the Atlantic Forest. The biggest variety of this plant family appears between Parana and Bahia states (Santos et al., 2005). Its characteristic form of rosette, usually with large hems at the bases, forms a water and nutrient reservoir that characterises a peculiar microenvironment that provides good conditions for its use by various animal species (Laessle, 1961; Peixoto, 1977). For Oliveira and Navas (2004), the characteristics of an individual bromeliad plant determine the microhabitat quality for oviposition, so a direct relation between the plant choice and reproductive success would be expected. As a result, during the bromeligen anurans evolutionary history, natural selection probably favoured the ability of evaluate bromeliads as egg-laying sites (Oliveira and Navas, 2004).

Scinax argyreornatus (Miranda-Ribeiro, 1926) was considered an habitual bromeliad-dweller by Narvaes et al. (2009), being an endemic species to the Atlantic Rain Forest, occurring between Bahia and São Paulo states (Teixeira and Vrcibradic, 2004). The species displays forest habits, and after strong rains, many males call on the plants around temporary puddles (Izeckson and Carvalho-e-Silva, 2001). We investigated a $S$. argyreornatus population that presents a common association with native bromeliads occurring only in a reduced part of the Rain Forest remains of the area in the municipality of Porto Real, in the state of Rio de Janeiro, Brazil. Although this behaviour may be common in this species, there is no detailed description of an ecologic relation that may differ according to population and locality. Therefore, we propose to identify the characteristics of the bromeliad environment chosen by $S$. argyreornatus as a microhabitat, evaluating the interaction level of this species with the bromeliads in this Rain Forest remnant area of Porto Real.

\section{Material and Methods}

\subsection{Study area and data collection}

The study area is a Rain Forest remnant, located in the city of Porto Real (22 ${ }^{\circ} 24^{\prime} \mathrm{S}$ and $\left.44^{\circ} 17^{\prime} \mathrm{W}\right)$, Rio de Janeiro state, Brazil, in approximately $400 \mathrm{~m}$ asl. In this area we established four transects that were $10 \mathrm{~m}$ wide and occupied the whole transversal extension of the forest (100 to $120 \mathrm{~m}$ ). These transects were $40 \mathrm{~m}$ apart from each other. We visited the area weekly, from July of 2006 to February of 2007, and gathered data over 320 hours of sampling effort in the field. Inside this sample area all bromeliads, up to two metres high from the soil, were inspected to verify the water volume retained, with a $60 \mathrm{~mL}$ syringe of $1 \mathrm{~mL}$ precision, and anuran presence. For each examined bromeliad, the number of leaves and leaf axils was registered, along with base width and longest leaf length, largest diameter and plant height (from the rosette base to the top of the highest leaf) and its distance from the soil. The $\mathrm{pH}$ was analysed with the LabconTest kit. The typical monthly rainfall was measured with a pluviometer installed in the location. The relative humidity ( $\mathrm{RH} \%$ ) was measured through the digital thermo-hygrometer Incoterm ${ }^{\circledR}$ precision $\pm 5 \mathrm{RH} \% \mathrm{e} \pm 1{ }^{\circ} \mathrm{C}$.

\subsection{Statistic and ecological analysis}

To evaluate the anuran concentration per bromeliad, we considered the Concentration of Relative Dominance (CRD) of individuals per bromeliad species (Silveira Neto et al., 1976). Being (Equation 1):

$\mathrm{CRD}=(i / \mathrm{t}) \times 100$

where: $i$ is the total of individuals of one species, and $t$ is the total of sampled individuals. Water volume was considered as a possible element of choice by anurans, as well as the physical characteristics per sampled plant (the water volume in the leaf axils and in the plant centre, the number of leaves and leaf axils, base width and biggest leaf length, the biggest diameter and plant height - from the rosette base to the top of the highest leaf). These elements were tested with ANOVA, however, whenever there were significant differences the Tukey test was used to compare means a posteriori to the confidence level of $\mathrm{p}<0.01$.

The climatic parameter influence on species wealth and constancy was verified through a correlation matrix (Zar, 1996) based on the weekly measured numbers of the four variables. A relation was verified between the anurans CRD and the variables: 1) rainfall $\mathrm{mm}$; 2) temperature ${ }^{\circ} \mathrm{C}$; 3) water volume $\mathrm{mL}$ in the central tube and 4) leaf axils; in relation to the bromeliads Quesnelia arvensis 
(Vell.) Mez, Neoregelia johannis (Carrière) L.B. Smith and Aechmea sp. Ruiz e Pav. The variation of these data during the sampling period is shown in a Pareto diagram.

The occupation choice was evaluated by Bodenheimer's Constancy (1955) apud Silveira Neto et al. (1976) being (Equation 2):

$\mathrm{C}=(p \times 100) / N$

where: $p$ is the number of bromeliads including the studied anuran species, and $N$ is the total samples number. The presence of $S$. argyreornatus per occupied bromeliad was considered: Constant > 50\%; Accessory 25 a $50 \%$ and Accidental $<25 \%$.

\section{Results}

The plants sheltering frogs were distributed in three species of bromeliads: Quesnelia arvensis, Neoregelia johannis and Aechmea sp. We registered 604 bromeliads being $Q$. arvensis $(\mathrm{n}=268), N$. johannis $(\mathrm{n}=259)$ and Aechmea sp. $(\mathrm{n}=77)$. We observed the occurrence of 183 S. argyreornatus individuals associated with these three bromeliads species. Between them, Aechmea sp. was the bromeliad with highest constancy $(\mathrm{C}=49 \%)$, followed by $Q$. arvensis $(\mathrm{C}=31 \%)$ and $N$. johannis $(\mathrm{C}=23 \%)$, presenting differences among species. Based on Bodenheimer's Constancy calculus and the use of these three bromeliads species as shelter, it is perceived that the anuran uses Aechmea sp. and $Q$. arvensis in an accessory form, while $N$. johannis is used in an accidental form.

When establishing the correlation of anuran concentration with 1) plant region (leaf axils or central tube) and 2) abiotic factors such as relative humidity $(\mathrm{RH} \%)$ and temperature $\left({ }^{\circ} \mathrm{C}\right)$, only the $\mathrm{RH} \%$ showed a significant correlation, not depending on the occupation place (Table 1). However, correlating the $\mathrm{RH} \%$ separately per bromeliad species, Aechmea sp. presented a null correlation while $Q$. arvensis and $N$. johannis a positive significant one (Figure 1; Table 2).

As the anuran choice element, in relation to the accessory and accidental shelter, we evaluate the physical characteristics of sampled plants (the water volume in the leaf axils and in the plant centre, the number of leaves and leaf axils, base width and biggest leaf length, the biggest diameter and plant height - from the rosette base to the top of the highest leaf). Each of these elements were compared with the ANOVA test with the intention of verifying the possible statistical differences among bromeliad species and determining the possible anuran choice element. Evaluating the results found in the ANOVA test and testing the differences with the Tukey test, we perceive that the number of leaves, the number of axils and the leaf length are similar between the $Q$. arvensis and Aechmea sp. whereas $N$. johannis is different (Table 3 ). As for the variable of volume of water in the axils, in the centre and the height of the plant from the rosette base to the top of the leaf, these present differences between the three species not characterising homogeneity of characteristics that defines the $S$. argyreornatus choice. The $\mathrm{pH}$ was constant during the whole period $(\mathrm{pH}<6.5)$, not having difference between the bromeliad species, not even in relation to the anuran presence or absence.

The rainfall volume just presented alteration during the rainy period $(18 \mathrm{~mm})$ which corresponds to the four first study weeks, having different volumetric water retention for each species. However, when the water volume per bromeliad, in relation to $S$. argyreornatus CRD, is tested with Spearman's correlation, this is null.

\section{Discussion}

As observed by Oliveira and Navas (2004), we also registered typical rain water $\mathrm{pH}(\mathrm{pH}<6.5)$ in the water accumulated in the plants. However, we did not observe any difference between occupied and non-occupied plants, although the authors have noticed that the most occupied plants are the ones with less acid water $\mathrm{pH}$. For Oliveira and Navas (2004), the bromeliad characteristics influence the bromeligen anuran's choice and natural selection probably developed the ability of evaluation of the bromeliads with more favourable characteristics. Because S. argyreornatus is not a bromeligen species, it may not present a subtle ability to evaluate bromeliad micro-environment.

Table 1. Correlation between relative humidity (UR\%) and temperature $\left({ }^{\circ} \mathrm{C}\right)$ in relation to $S$. argyreornatus concentration (CRD) and correlation between S. argyreornatus concentration and the water volume in the central tube and in the leaf axils of bromeliads.

\begin{tabular}{lcccc}
\hline & CRD $\times$ UR\% & CRD $\times{ }^{\circ} \mathbf{C}$ & $\begin{array}{c}\text { CRD } \times \text { volume } \\
\text { (central tube) }\end{array}$ & $\begin{array}{c}\text { CRD } \times \text { volume } \\
\text { (Axil) }\end{array}$ \\
\hline $\mathrm{n}$ (pairs) & 31 & 31 & 31 & 31 \\
$\mathrm{r}$ (Pearson) & 0.96 & 0,62 & 0.60 & 0.68 \\
$\mathrm{IC}$ 95\% & 0.93 to 0.98 & 0.34 to 0.80 & 0.31 to 0.79 & 0.43 to 0.83 \\
$\mathrm{IC} \mathrm{99 \%}$ & 0.91 to 0.99 & 0.23 to 0.84 & 0.20 to 0.83 & 0.33 to 0.87 \\
$\mathrm{R}^{2}$ & $0.93^{(\mathrm{s})}$ & $0.68^{(\mathrm{ns})}$ & $0.66^{(\mathrm{ns})}$ & $0.76^{(\mathrm{ns})}$ \\
$\mathrm{T}$ & 19.99 & 4.22 & 4.04 & 4.99 \\
$\mathrm{GL}$ & 29 & 29 & 29 & 29 \\
$\mathrm{P}$ & $<0.0001$ & 0.0002 & 0.0012 & 0.0004 \\
Correlation matrix & 1.000 & 0.9312 & 0.9103 & 0.9802 \\
\hline
\end{tabular}

${ }^{(\mathrm{s})}$ Significant correlation, ${ }^{(\mathrm{ns})}$ non-significant correlation to $\mathrm{p}<0.0001$ with $\mathrm{n}$ - 2 degrees of freedom. 


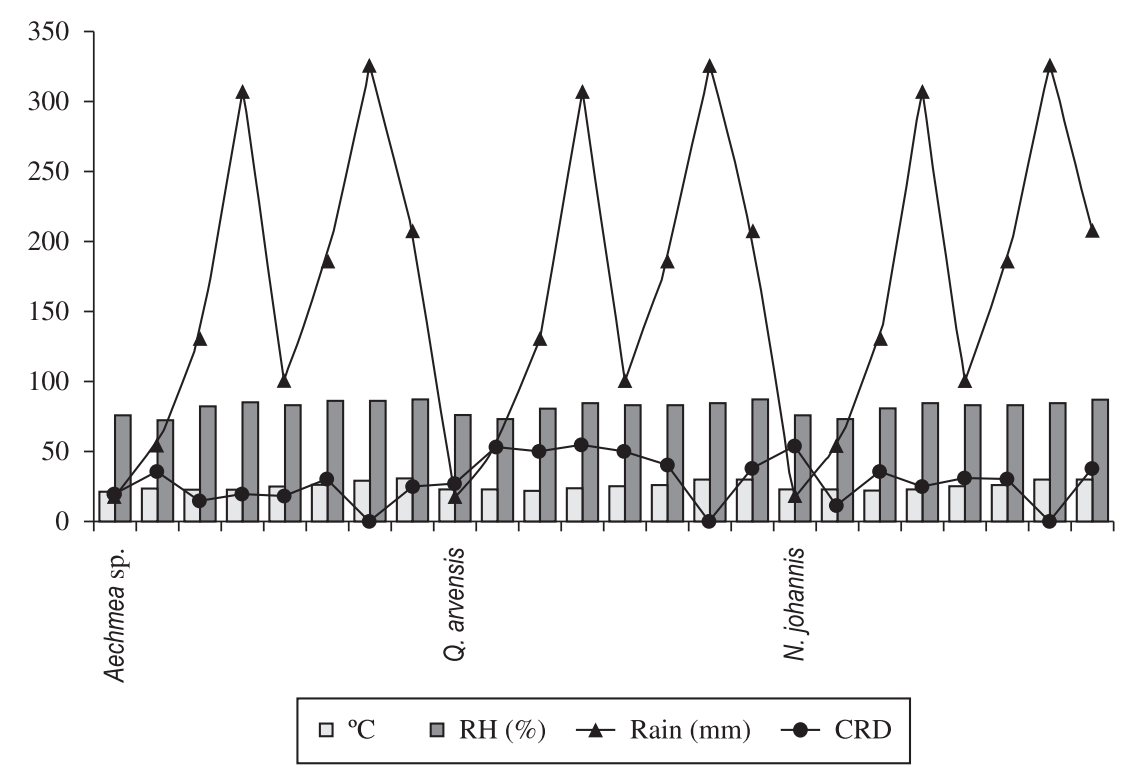

Figure 1. Variation of abiotic factors and concentration of S. argyreornatus in the three bromeliad species during the sampling period.

Table 2. Correlation between relative humidity (UR\%) and S. argyreornatus concentration (CRD) on occupied bromeliads.

\begin{tabular}{lccc}
\hline & Q. arvensis & N. johannis & Aechmea sp. \\
\hline n (pares) & 32 & 32 & 32 \\
r (Pearson) & 0.96 & 0.83 & -0.01 \\
IC 95\% & 0.93 to 0.98 & 0.68 to 0.92 & -0.36 to 0.34 \\
IC 99\% & 0.91 to 0.99 & 0.61 to 0.92 & -0.46 to 0.44 \\
R $^{2}$ & $0.93^{\mathrm{s}}$ & $0.69^{\mathrm{s}}$ & $0.0002^{\text {ns }}$ \\
t & 20.37 & 8.22 & -0.07 \\
GL & 30 & 30 & 30 \\
p & $<0.0001$ & $<0.0001$ & 0.94 \\
Correlation matrix & 1.0000 & 1.0000 & 0.10 \\
\hline
\end{tabular}

${ }^{(\mathrm{s})}$ Significant correlation, ${ }^{(\mathrm{ns})}$ non significant correlation to $\mathrm{p}<0.0001$ with $\mathrm{n}-2$ degrees of freedom.

Table 3. Analysis of variance and Tukey test for the organographic parameters of the studied bromeliads.

\begin{tabular}{|c|c|c|c|c|c|c|c|}
\hline \multicolumn{3}{|c|}{ ANOVA } & \multicolumn{5}{|c|}{ Tukey } \\
\hline Bromeliad & $\mathbf{F}$ & (p) & Organography & $\begin{array}{c}\text { Organographic } \\
\text { average }\end{array}$ & Difference & Q & (p) \\
\hline \multirow[t]{3}{*}{ Q.a } & 228,8656 & $<0.01$ & Leaves number & Q. $a \times A . \mathrm{sp}$. & 8.56 & 7.36 & ns \\
\hline & & & & $Q . a \times N . j$ & 14.21 & 4.43 & $<0.01$ \\
\hline & & & & $N . j \times A . \mathrm{sp}$. & 65.55 & 33.95 & $<0.01$ \\
\hline \multirow[t]{3}{*}{ A.sp. } & 888,2585 & & Axils number & Q.a $a$ A.sp. & 5.65 & 2.93 & ns \\
\hline & & & & $Q . a \times N . j$ & 75.20 & 38.95 & $<0.01$ \\
\hline & & & & $N . j \times A . \mathrm{sp}$. & 46.34 & 24.00 & $<0.01$ \\
\hline \multirow[t]{6}{*}{$N . j$} & 225,7595 & & Leaf length & Q.a $a \times A . \mathrm{sp}$. & 4.93 & 2.95 & ns \\
\hline & & & & $Q . a \times N . j$ & 64.67 & 38.75 & $<0.01$ \\
\hline & & & & $N . j \times A . s p$. & 72.17 & 55.94 & $<0.01$ \\
\hline & & & Diameter & $Q . a \times A . s p$ & 7.62 & 4.56 & $<0.05$ \\
\hline & & & & $Q . a \times N . j$ & 46.34 & 24.00 & $<0.01$ \\
\hline & & & & $N . j \times A . s p$ & 100.83 & 78.16 & $<0.01$ \\
\hline
\end{tabular}

ns - non significant with $\mathrm{p}<0.01$ (significance at 99\%) and $\mathrm{p}<0.05$ (significance at 95\%); Q.a = Quesnelia arvensis, N.j. = Neoregelia johannis, A.sp. = Aechmea $\mathrm{sp}$. 
Our studies allowed us to infer that, for S. argyreornatus, bromeliad organographic structure and the relative humidity are conditions that interfere in its choice behaviour, being that Aechmea sp. and Q. arvensis present physical characteristics such as leaf number, axil number, leaf length and diameter that forms an organographic plant arrangement favourable to its accessory permanence choice, while for $N$. johannis this occurs in accidental form. It seems that $S$. argyreornatus is capable of discriminating these bromeliad characteristics that are favourable to its permanence in Aechmea sp. and Q. arvensis.

The null correlation between the animal CRD in bromeliads and rainfall index seems to be favoured by the reproductive habit of this species not including these plants as an egg-laying site (Izecksohn and Carvalho-eSilva, 2001; Teixeira and Vrcibradic, 2004). Though, in spite of the temporary puddle formation being initiated in November, 2006, the area remaining flooded until March, 2007 , the only month that the anurans were not observed in the bromeliads was in January, 2007, the month with the highest rainfall index $(325,7 \mathrm{~mm})$, which maybe has represented the period of more reproductive concentration of this population. According to Izecksohn and Carvalhoe-Silva (2001) S. argyreornatus males call in great number after strong rains, so, they could have stopped using the shelter of the bromeliads during this period. Therefore bromeliad use was not exclusive only in drought periods.

Peixoto $(1977,1995)$ and Izecksohn and Carvalho-eSilva (2001) do not cite $S$. argyreornatus as a species related to bromeliads, as do Teixeira et al. (2002). Schineider and Teixeira (2001) and Haddad et al. (2008) mention the occurrence of this species in bromeliads without any comment about association degree or ecological complexity in this relation. Narvaes et al. (2009) show that this species is a habitual bromeliad-dweller in sandbank ecosystems.

Conflating our results with those of Peixoto (1977, 1995), where obligatory bromeliad-dwellers are found in bromeliads every year, $S$. argyreornatus must be considered eventual bromeliads-dwellers, because they do not seem to occupy these plants during the highest rainfall period. Additionally, when we evaluated this species behaviour using Bodenheimer's Constancy (1955) apud Silveira Neto et al. (1976), the occupation was accidental $(<25 \%)$ in $N$. johannis and accessory (25 a 50\%), Aechmea sp. and $Q$. arvensis. This would not be expected for obligatory bromeliad-dwellers, species in which the occupation constancy is above $50 \%$, that is, constant. So, the anuran classification in regard its association degree to bromeliads, as obligatory or eventual bromeliad-dwellers, depends on these two evaluations, mainly if evaluated in places and/or periods where the drought is not so intense.

Acknowledgements - We thank Porto Real Ceramics, in the person of Mr. Eduardo and his wife, for preserving one of last
Atlantic Rain Forest remains of Porto Real/RJ and for providing access for our studies; the BIOMA NGO for the research incentive and Walter Miguel Krans and Luiz Filipe Varella for helping to identify the bromeliads.

\section{References}

HADDAD, CFB., TOLEDO, LF. and PRADO, CPA., 2008. Anfíbios da Mata Atlântica. São Paulo: Neotropica.

IZECKSOHN, E. and CARVALHO-E-SILVA, SP., 2001. Anfíbios do Município do Rio de Janeiro. Rio de Janeiro: UFRJ.

LAESSLE, AM., 1961. A microlimnological study of Jamaican bromeliads. Ecology, vol. 42, no. 3, p. 499-517. http://dx.doi. org/10.2307/1932236

LEHTINEN, R.M., 2002. The use of screw pines (Pandanus spp.) by amphibians and reptiles in Madagascar. Herpetological Bulletin, vol. 82, p. 20-25.

NARVAES, P., BERTOLUCI, J. and RODRIGUES, MT., 2009. Composição, uso de hábitat e estações reprodutivas das espécies de anuros da floresta de restinga da Estação Ecológica Juréia-Itatins, sudeste do Brasil. Biota Neotropica, vol. 9, no. 2, p. 117-124. http://dx.doi.org/10.1590/S1676-06032009000200011

OLIVEIRA, FB. and NAVAS, CA., 2004. Plant selection and seasonal patterns of vocal activity in two populations of the Brazilian treefrog Scinax perpusillus (Anura, Hylidae). Journal of Herpetology, vol. 38, no. 3, p. 331-339. http://dx.doi. org/10.1670/205-03A

PEIXOTO, OL., 1977. Anfíbios anuros associados às bromeliáceas nos Estados do Rio de Janeiro e Espírito Santo. Rio de Janeiro: Universidade Federal do Rio de Janeiro. Dissertação de Mestrado.

-, 1995. Associação de anuros a bromeliáceas na Mata Atlântica. Revista Série Ciências da Vida, vol. 17, no. 2, p. 75-83.

SANTOS, AJ., BITTENCOURT, AM. and NOGUEIRA, AS., 2005. Aspectos econômicos da cadeia produtiva das bromélias na região metropolitana de Curitiba e Litoral Paranaense. Floresta, vol. 35 , no. 3 , p. $409-417$.

SCHINEIDER, JAP. and TEIXEIRA, RL., 2001. Relacionamento entre anfíbios anuros e bromélias da restinga de Regência, Linhares, Espírito Santo, Brasil. Iheringia. Série Zoologia, vol. 91, p. 41-48.

SILVEIRA NETO, S., NAKANO, O., BARBIN, D. and NOVA, VAN., 1976. Manual de Ecologia dos Insetos. São Paulo: CERES.

TEIXEIRA, RL., SCHINEIDER, JAP. and ALMEIDA, GI., 2002. The ocurrence of amphibians in bromeliads from a Southeastern Brazilian restinga habitat, with special reference to Aparasphenodon brunoi (Anura, Hylidae). Brazilian Journal of Biology, vol. 62, no. 2, p. 263-268. http://dx.doi.org/10.1590/S1519-69842002000200010

TEIXEIRA, RL. and VRCIBRADIC, D., 2004. Ecological aspects of Scinax argyreornatus (Anura, Hylidae) from a cacao plantation in Espírito Santo state, southeastern Brazil. Boletim do Museu de Biologia Mello Leitão, vol. 17, p. 35-43.

ZAR, JH., 1996. Biostatistical Analysis. 3rd ed. New Jersey: Prentice Hall. 
